\title{
ESTIMATING FLUVIAL DISCHARGE IN THE CARIBBEAN SEABOARD OF COLOMBIA: MAGNITUDE, VARIABILITY AND EXTREME EVENTS
}

\author{
Juan Camilo Restrepo ${ }^{1,2}$, Juan Carlos Ortiz ${ }^{1,2}$, Mauro Maza ${ }^{1}$, Luis Otero ${ }^{1}$, Manuel Alvarado², y \\ Julián Aguirre ${ }^{3}$
}

\begin{abstract}
Monthly freshwater discharge data of ten rivers draining into the Caribbean Sea in the northern of Colombia (Caribbean alluvial plain) are analyzed. The data are used to quantify the magnitude, to estimate long-term trends, and to evaluate variability patterns of freshwater discharges into the ocean. These Colombian rivers contribute with $\sim 340.9 \mathrm{~km}^{3} \mathrm{yr}^{-1}$ of freshwater into the Caribbean Sea. The Magdalena River delivers the largest discharge, with a mean discharge at Calamar of $205.5 \mathrm{~km}^{3} \mathrm{yr}^{-1}$ which represents $26 \%$ of the total fluvial discharge into this basin. From 2000 to 2010 the annual streamflow of these rivers rose up three fold. However, only the Mulatos, Canal del Dique, Magdalena, and Fundación Rivers have significant statistical upward trends. The concurrence of the major oscillation processes and the maximum power of the 3-7 year fluctuation defined a period of intense hydrological activity around 1998-2002. Wavelet spectrum analysis indicated a change in the variability patterns of fluvial systems between 2000 and 2010, characterized by a shift toward a domain of quasi-decadal processes (8-12 years). The Intertropical Convergence Zone (ITCZ), ENSO events, and quasi-decadal climate processes (e.g. sea surface temperatures over tropical North Atlantic, Pacific Decadal Oscillation) are the main factors controlling fluvial discharge variability of these fluvial systems.
\end{abstract}

Keywords: Mann-Kendal analysis, Wavelet analysis, Magdalena River, hydrologic oscillation, Caribbean Sea.

\section{INTRODUCTION}

Fluvial discharges play a major role in the hydrological cycle and thermodynamic stability of oceans, as well as in biogeochemical cycles. Therefore, quantifying the magnitude and variability of fluvial discharges is a key element within coastal and continental shelf oceanography. Dramatic changes in hydrological regimes, high seasonal variability, and a crescent anthropogenic intervention, have been reported in several major rivers of the world during the last two decades (Walling and Fang, 2003). Several studies have analyzed streamflow changes for detecting significant trends, identifying major oscillations periods, and determining relationships between hydrological responses and climatic forcings (e.g. Probst and Tardy, 1987; Pekarova et al., 2003; Walling and Fang, 2003; Labat et al., 2005; Hungtinton, 2006; Pasquini y Depetris, 2007; Milliman et al., 2008). The annual streamflow of a river may be viewed as an integration of the annual or interannual climatic fluctuations which characterize its basin. Thus, several authors use river flows as a sort of climatic indicator and the longperiod streamflow fluctuations to identify and characterize the different climatic periods (Pekarova et al., 2003; Milliman et al., 2008). Through time series analysis of annual streamflow data of fifty major rivers, distributed all around the world, Probst and Tardy (1987) pointed out that during the first half of the last century Europe and Asia were affected by a significant humid regime. On the contrary, Africa, North and South America underwent this same response throughout the last half of that century. Probst and Tardy (1987) concluded that in any given region with a relatively small area, the streamflow fluctuations are generally synchronous and closely related to pressure oscillations of different scales.

In recent years, some studies have shown contrasting results regarding streamflow trends, but there are some agreements on identifying major oscillatory components which control streamflow fluctuations. According to Pekarova et al. (2003) there was no evidence of significant trends (neither increasing nor decreasing) in the annual streamflow of the 24 major rivers of the world; but they identified the alternance of wet and dry periods, and extreme cycles of high-low discharge almost every 3.6, 7, 13-14, 20-22 and 28-32 years. Besides, Pekarova et al. (2003) identified a geographical control in these hydrological shifts, thus the extreme cycles do not occur simultaneously around the world. Milliman et al. (2008) indicated that between 1951 and 2000 cumulative discharge for 137 rivers, representative of the entire regions of the world, remained statistically unchanged offering little support to a global intensification of the hydrological cycle. However, they noted significant changes in individual rivers and at regional levels. For instance, streamflow from large South American rivers

\footnotetext{
${ }^{1}$ Océano y Atmósfera - Grupo de Física Aplicada, Departamento de Física, Universidad del Norte, km 5 vía Puerto Colombia, Barranquilla, Colombia. restrepocj@uninorte.edu.co

2 Instituto de Estudios Hidráulicos y Ambientales, Departamento de Ingeniería Civil y Ambiental, Universidad del Norte, km 5 vía Puerto Colombia, Barranquilla, Colombia.

${ }^{3}$ Centro Integral para el Desarrollo de la Investigación, Universidad Pontificia Bolivariana, Medellín, Colombia.
} 
(Amazon, Orinoco, Magdalena) remained relatively constant, with the noteworthy exception of the Parana river, whose discharges rose a $45 \%$ throughout 1950 - 2000; whereas most rivers draining into the Mediterranean sea and Indic ocean have declined their streamflows considerably (Milliman et al., 2008).

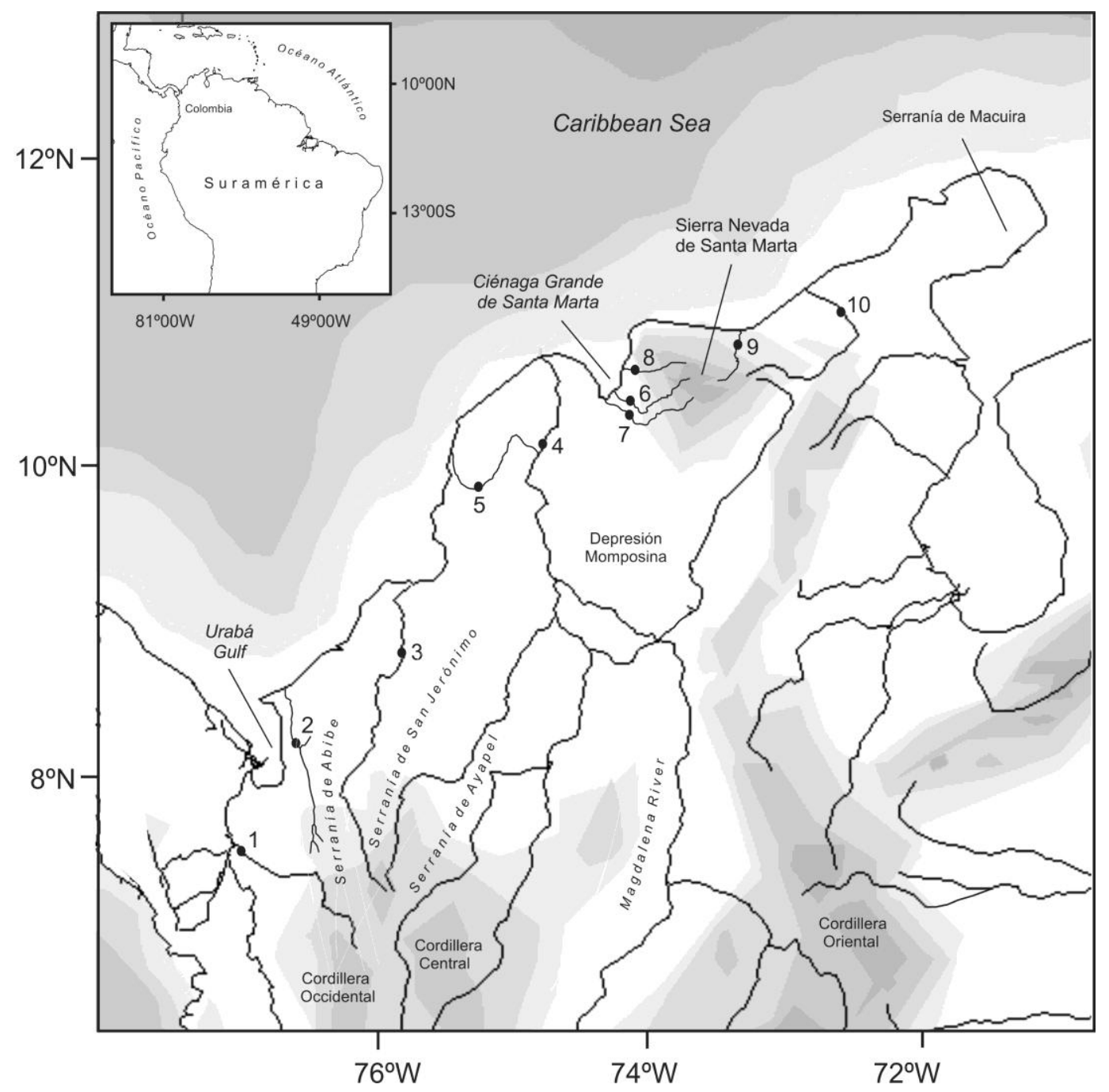

Figure 1. Caribbean plain of Colombia in northwest South America. Major topographic features, selected rivers and gauge stations: 1. Sucío River; 2. Mulatos River; 3. Sinú River; 4. Magdalena River (Calamar); 5. Canal del Dique; 6. Aracataca River; 7. Fundación River; 8. Frío River; 9. Palomino River; 10. Ranchería River.

Magdalena River (Colombia) contributes with the main supply of freshwater and suspended sediment into the Caribbean Sea. Despite the importance of this river in regulating coastal and estuarine processes on a regional level, several aspects controlling hydro-sedimentary dynamics remain poorly understood. Colombian Caribbean Rivers have shown a direct effect on littoral morphodynamic and coastal circulation processes. Some authors have analyzed the relationship between streamflow of Colombian rivers and ENSO phenomenon (Mesa et al., 1997; Restrepo and Kjerfve, 2000; Gutierrez and Declet, 2001). The ENSO warm phase causes an increment in the mean temperature of air masses, a decrease in the soil moisture and vegetal activity, a drop in rainfall rates, and consequently the streamflow of rivers decreases in the west, north and central areas of Colombia; opposite anomalies characterize the ENSO cold phase, hence intense and abundant rainfalls generate a significant increase of streamflows (Mesa et al. 1997, Poveda et al. 2001). Statistical analysis of annual streamflow data and SOI anomalies indicated earlier and stronger ENSO-related effects in basins located in western, central and northern zones of the country; but weaker and later in those basins located in eastern and 
southeastern zones (Mesa et al., 1997; Poveda et al., 2001). In particular, it has been estimated that ENSO phenomenon might explains up to $65 \%$ of streamflow interannual variability, in rivers such as Magdalena, Cauca, Cesar, Rancheria, and Sinú (Restrepo and Kjerfve, 2000; Gutierrez and Declet, 2001). However, there are little insights about other oscillation periods, their relationships with known climatic forcings, and the corresponding hydrological responses, particularly in rivers draining the Caribbean alluvial plain (northern of Colombia) (Figure 1). The lack of knowledge on these subjects has hampered the effective implementation of water resource management plans, oriented to prevent or mitigate the adverse effects of hydrologic events. In recent years such plans are becoming more important, due to the increase in the number, duration and intensity of hydrological events such as floods and droughts. This study analyzes hydrological data (monthly mean streamflow) of ten drainage basins of the Caribbean plain of Colombian, in order to estimate: (1) recent fluvial discharges into the Caribbean Sea, (2) seasonal and interannual variability patterns, and (3) historical trends and extreme events effects on freshwater discharges into the ocean.

\section{STUDY AREA}

The Caribbean plain of Colombia is located in the northernmost of South America. It extends from the Darien tropical rainforest, in the Colombia-Panama border, to the Peninsula de La Guajira in the east, and the slopes of the Cordillera de los Andes in the south (Figure 1). It comprises extensive lowlands with heights below $100 \mathrm{~m}$., plateaus with heights between $200 \mathrm{~m}$ and $1000 \mathrm{~m}$ in the southwest (Serranías de Abibe, San Jerónimo and Ayapel) and northeast (Serranía de Macuira), and one of the highest coastal mountain of the world, named Sierra Nevada de Santa Marta, with heights up to $5000 \mathrm{~m}$. (Restrepo and Kjerfve, 2004). The rivers selected in this study originate from headwaters in the Andes Cordillera (Sucío, Mulatos, Sinú and Magdalena Rivers) and the Sierra Nevada de Santa Marta (Aracataca, Fundación, Frío, Palomino and Rancheria Rivers) (Figure 1). The headwaters of the Sucío, Mulatos and Sinú Rivers are located in the Nudo de Paramillo, where the Cordillera Occidental bifurcates into the Serranías de Abibe, San Jerónimo and Ayapel. The Sucío River runs northwestward from its headwater, at $4080 \mathrm{~m}$., before joins to the Atrato River, where it turns to the north until empties into the Uraba gulf. The Mulatos River drains a plateau in the Serranía de Abibe, along 115 km from south to north, before discharging directly into the Caribbean Sea. The Sinú River has a drainage basin of $14.7 \times 10^{3} \mathrm{~km}^{2}$, which comprises a steep mountainous zone in the headwater, an alluvial valley formed by the Serranías de Abibe and San Jerónimo, and extensive alluvial flood plains where significant water storage occur (i.e. lagoon system) (Serrano, 2004). The Sinú River measures $415 \mathrm{~km}$, from its headwater, at $3960 \mathrm{~m}$, until its mouth in the Caribbean Sea (Serrano, 2004). The Magdalena is the largest fluvial system in the Caribbean plain, with an extension of $1540 \mathrm{~km}$ and a drainage basin of $257.4 \times 10^{3} \mathrm{~km}^{2}$ (Restrepo and Kjerfve, 2004). Its headwater is located at $3600 \mathrm{~m}$. in the Cordillera Central, in the south of Colombia $\left(1^{\circ} 45^{\prime} \mathrm{N}, 76^{\circ} 30^{\prime} \mathrm{W}\right)$; the river runs northward along the Magdalena valley, between the Cordillera Central and Oriental, before turn to the west and enter in an active tectonic depression named "Depresión Momposina", where significant sediment deposition and storage occur. At this site the Magdalena River undergoes a meandering course and receives the fluvial inputs of Cesar, Cauca and San Jorge Rivers. Once the Magdalena River crosses the "Depresión Momposina" heads to the north to Calamar, where two distributaries are formed; one heads to the northwest toward Cartagena bay (Canal del Dique) and the major distributary continues to the north toward Magdalena Delta in the Caribbean Sea (Restrepo and Restrepo, 2005). The rivers of the Sierra Nevada de Santa Marta drain small mountainous basins $\left(<5000 \mathrm{~km}^{2}\right)$ with steep gradients and limited alluvial flood plains, except the Rancheria River which crosses extensive lowlands in the Peninsula de la Guajira. The Frío, Aracataca and Fundación Rivers drain the western slopes of the Sierra Nevada de Santa Marta and empty into the Ciénaga Grande de Santa Marta, which has a direct connection with the Caribbean Sea. The Palomino and Rancheria Rivers drain the eastern slopes of the Sierra Nevada de Santa Marta, from southwest to northeast, and discharge directly into the Caribbean Sea (Figure 1).

The meridional oscillation of the Intertropical Convergence Zone (ITCZ) controls the annual hydrological cycle, defining two rainy seasons in the Caribbean plain. The first season extends from may to june, when the ITCZ is migrating from north to south, whereas the second and stronger season goes from september to october, when the ITCZ shifts northward. However, different local patterns can be distinguished as consequence of orographic effects caused by Andes range slopes and Sierra Nevada de Santa Marta, and the westerly jet wind currents (i.e. Chocó Jet) (Mesa et al., 1997; Poveda, 2004). Hence, the western of the Caribbean plain, close to the Darien tropical rainforest, and the Sierra Nevada de Santa Marta exhibit the maximum rainfall rates and the lower mean annual temperatures, with values 
of $>2000 \mathrm{~mm} \mathrm{yr}^{-1}$ and $<20^{\circ} \mathrm{C}$, respectively. On the contrary, the lowlands are hotter and drier with mean annual temperatures $>27^{\circ} \mathrm{C}$ and rainfall rates below to $1000 \mathrm{~mm} \mathrm{yr}^{-1}$ (Mesa et al., 1997). At higher time scales, the major anomalies in hydrological patterns have been associated to both phases of El Niño/Southern Oscillation (ENSO). The ENSO warm phase (El Niño) promotes an increase in mean air temperatures, a decrease in soil moisture and vegetation index, and thus the rainfall rates diminishes. The opposite anomalies during ENSO cold phase (La Niño) generate abundant and intense rainfalls (Poveda et al., 2001; Poveda, 2004).

\section{DATA AND METHODS}

The IDEAM (Instituto de Hidrología, Meteorología y Estudios Ambientales de Colombia) provides monthly freshwater discharge in ten drainage basins with different climatological and topographical settings along the Caribbean coast of Colombia (Figure 1 and Table 1). The selection of the different rivers and its corresponding gauging stations was based on two important conditions: (1) the gauging stations are located close to the downstream part of the basin; and (2) its hydrological data record is longer than thirty years. Water discharge time series ranges between 32 and 70 years. Continuity and homogeneity test were applied. Time series analyses were carried out, including: (1) fluvial indexes calculation, (2) Mann-Kendal Test (Gradual Trend Test) to identify and quantify long-term hydrological trends (Yue et al., 2002), (3) Continuous Wavelet Transform analyses (Morlet Wavelet Spectrum) to estimate periodicities and seasonal and interannual variability patterns (Shumway and Stoffer, 2004; Labat, 2005), and (4) cross correlation between monthly streamflow and monthly anomalies of Southern Oscillation Index (SOI) to quantify the effects of ENSO in fluvial discharges. Monthly SOI anomalies were obtained from NOAA - Climate Prediction Center (NOAA, 2012).

\begin{tabular}{|c|c|c|c|c|c|}
\hline \multirow[b]{2}{*}{ River } & \multirow[b]{2}{*}{ Gauge Station } & \multicolumn{3}{|c|}{ Location } & \multirow[b]{2}{*}{ Record } \\
\hline & & $\begin{array}{l}\text { Elevation } \\
\text { (m.a.s.l.) }\end{array}$ & Longitude & Latitude & \\
\hline \multicolumn{6}{|l|}{ Andean Rivers } \\
\hline 1.Sucío & Mutata & 132 & $76^{\circ} 26 W$ & $7^{\circ} 13 \mathrm{~N}$ & $1976-2010$ \\
\hline 2.Mulatos & Pueblo Bello & 84 & $76^{\circ} 31 \mathrm{~W}$ & $8^{\circ} 12 \mathrm{~N}$ & $1977-2010$ \\
\hline $\begin{array}{l}\text { 3.Sinú } \\
\text { Magdalena }\end{array}$ & Cotoca Abajo & 5 & $75^{\circ} 51 \mathrm{~W}$ & $9^{\circ} 13 \mathrm{~N}$ & $1970-2010$ \\
\hline 4.Calamar & Calamar & 8 & $74^{\circ} 55 \mathrm{~W}$ & $10^{\circ} 15 \mathrm{~N}$ & $1941-2010$ \\
\hline $\begin{array}{l}\text { 5. Canal del Dique } \\
\text { Sierra Nevada Rive }\end{array}$ & Santa Helena & 3 & $75^{\circ} 24 \mathrm{~W}$ & $10^{\circ} 04 \mathrm{~N}$ & $1979-2010$ \\
\hline 6. Aracataca & Puente Ferrocarril & 37 & $74^{\circ} 11 \mathrm{~W}$ & $10^{\circ} 35 \mathrm{~N}$ & $1965-2010$ \\
\hline 7.Fundación & Fundación & 55 & $74^{\circ} 11 \mathrm{~W}$ & $10^{\circ} 31 \mathrm{~N}$ & $1958-2010$ \\
\hline 8.Frío & Rio Frío & 30 & $74^{\circ} 09 \mathrm{~W}$ & $10^{\circ} 34 \mathrm{~N}$ & $1965-2009$ \\
\hline 9.Palomino & Puente Carretera & 30 & $73^{\circ} 34 \mathrm{~W}$ & $11^{\circ} 14 \mathrm{~N}$ & $1973-2010$ \\
\hline 10.Ranchería & Hacienda Guamito & 76 & $72^{\circ} 37 \mathrm{~W}$ & $11^{\circ} 10 \mathrm{~N}$ & $1976-2007$ \\
\hline
\end{tabular}

The Mann-Kendall test (MKT) is a non-parametric rank based statistical test, used to detect and evaluated the significance of monotonic trends in time series (Yue et al., 2002). Non-parametric tests do not assume any special form for the distribution function of the data; it is therefore suitable for analysis of no normally distributed data. Hence, MKT has been considered as one of the most robust technique available to identify and estimate linear trends in environmental data, especially in time series analyses of fluvial discharges (e.g Yue et al., 2002; Garcia and Mechoso, 2005; Pasquini and Depetris, 2007; Milliman et al., 2008; Zhang et al., 2008). The Continuous Wavelet Transform (CWT) examines a time series using generalized local base functions (i.e. mother wavelets) that are stretched and translated with a resolution in both frequency and time (Pasquini and Depetris, 2007); it is a robust technique to evaluate time series containing non-stationary functions with different frequencies, providing a timescale localization of a signal. In consequence, CWT generates additional information such as trends, discontinuities and breakdown points, offering several advantages in comparison with traditional Fourier analyses. Besides, we applied power analysis - frequency range, computing the power of the continuous wavelet spectrum across time for a specified frequency band by integrating the interpolated wavelet spectrum surface (Labat, 2005). This test provides detailed information on the power of a specific periodicity across time. The CWT has been used to detect periodicities in streamflow series (e.g. Labat et al., 2004, 2005; Pasquini and Depetris, 2007; Labat, 2008, 2010; Rossi et al., 2009). 


\section{RESULTS AND DISCUSSION}

\section{Magnitude of Freshwater Discharge into the Caribbean Sea}

Rivers draining the Caribbean plain of Colombia contribute collectively with $\sim 340.9 \mathrm{~km}^{3} \mathrm{yr}^{-1}$ of freshwater into the Caribbean Sea (including Atrato River not considered in this study); this amount represent $43 \%$ of the total freshwater fluxes into this basin, estimated in $789.6 \mathrm{~km}^{3} \mathrm{yr}^{-1}$ (GRDC, 2009). The Magdalena River is the largest supply of freshwater into the Caribbean Sea, with a mean discharge at Calamar of $205.5 \mathrm{~km}^{3} \mathrm{yr}^{-1}$ that represent $26 \%$ of the total fluvial discharge (Table 2). Mean monthly streamflow of rivers draining the Caribbean plain of Colombia ranges between 4.63 and $6497 \mathrm{~m}^{3} \mathrm{~s}^{-1}$ (Table 2). The differences between maximum and mean monthly streamflow are up two orders of magnitude, whereas for maximum and minimum monthly streamflow can be as high as three orders of magnitude (Table 2). These ratios are commonly used to characterize discharge variability $\left(\mathrm{Q}_{\max } / \mathrm{Q}_{\min }\right)$ and flood regimes $\left(\mathrm{Q}_{\max } / \mathrm{Q}\right)$.

\begin{tabular}{|c|c|c|c|c|c|}
\hline River & $\begin{array}{c}A \\
\left(10^{3} \mathrm{~km}^{2}\right)\end{array}$ & $\begin{array}{c}Q \\
\left(m^{3} \mathrm{~s}^{-1}\right)\end{array}$ & $\begin{array}{c}Q \\
\left(k^{3} \mathrm{yr}^{-1}\right)\end{array}$ & $\underset{\left(m^{3} s^{-1}\right)}{Q_{\min }}$ & $\underset{\left(\mathrm{m}^{3} \mathrm{~s}^{-1}\right)}{Q_{\max }}$ \\
\hline Sucío & 4.52 & 278.57 & 8.78 & 22.80 & 1630.0 \\
\hline Mulatos & 0.01 & 4.63 & 0.14 & 0.01 & 35.4 \\
\hline Sinú & 14.73 & 398.09 & 12.56 & 29.10 & 858.2 \\
\hline \multicolumn{6}{|l|}{ Magdalena } \\
\hline Calamar & 257.41 & 6497.21 & 205.05 & 1520.00 & 16913.0 \\
\hline Canal del Dique & & 430.30 & 13.58 & 44.59 & 818.0 \\
\hline Aracataca & 0.93 & 14.70 & 0.46 & 0.78 & 360.0 \\
\hline Fundación & 1.87 & 28.20 & 0.88 & 1.80 & 872.5 \\
\hline Frío & 0.32 & 13.80 & 0.43 & 1.06 & 618.0 \\
\hline Palomino & 0.68 & 25.71 & 0.81 & 2.00 & 1000.0 \\
\hline Ranchería & 4.23 & 12.83 & 0.40 & 0.01 & 316.5 \\
\hline
\end{tabular}

Note. A: drainage area; Q: mean monthly freshwater discharge; $\mathrm{Q}_{\min }$ : minimum monthly freshwater discharge; $\mathrm{Q}_{\max }$ : maximum monthly freshwater discharge.

The Sierra Nevada Rivers with high to extremely high discharge variability also correspond to high flood regime. Considering that these fluvial systems have drainage areas smaller than $5.0 \times 10^{3} \mathrm{~km}^{2}$ in mountainous zones, the topographical setting is a primary factor controlling extreme flows and flood variability. The Andean rivers, which drain extensive plateaus or low-lying alluvial valleys, are characterized by low to medium discharge variability and low flood regime (Figure 2).

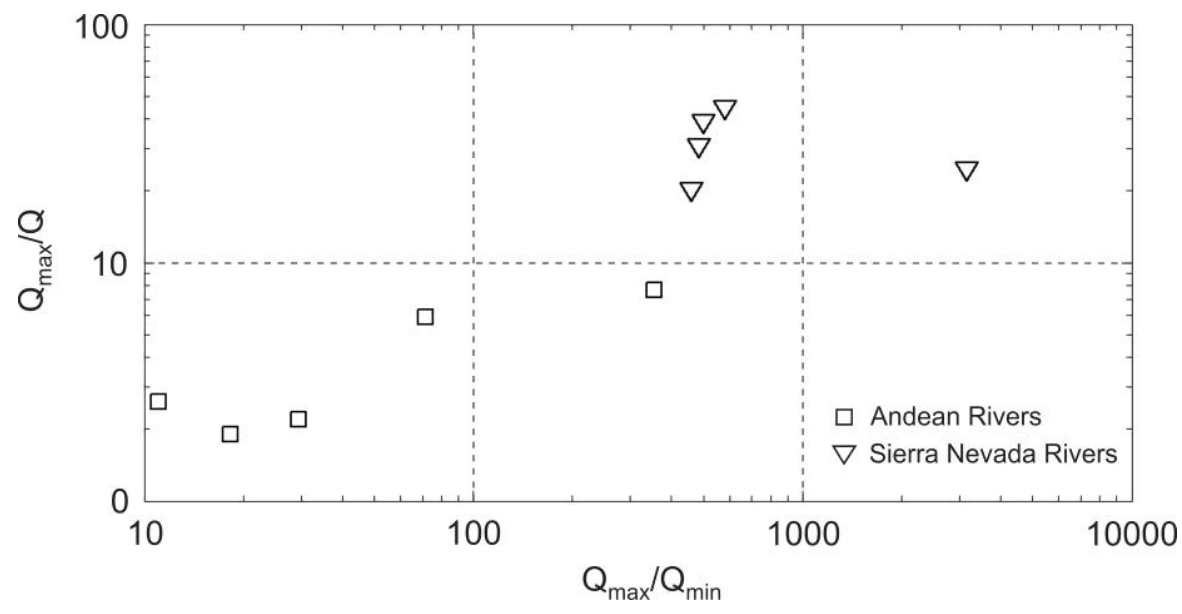

Figure 2. Discharge variability for rivers draining the Caribbean plain of Colombia. Ratio of maximum to mean monthly streamflow $\left(Q_{\max } / Q\right)$, and maximum to minimum monthly streamflow $\left(Q_{\max } / Q_{\min }\right)$.

\section{Historical Trends of Freshwater Discharge}

The Mann-Kendal test was applied to identify trends in streamflow time series. This test considers no trend in the time series as null hypothesis and calculates a standardized variable $(Z)$ to verify it. The null hypothesis is rejected for a significant level $\alpha$ if $Z>Z_{(1-\alpha / 2)}$; where $Z_{(1-\alpha / 2)}$ is the standard value of a normal distribution with probability of $\alpha / 2$ (Yue et al., 2002). 


\begin{tabular}{|c|c|c|c|c|c|c|}
\hline River & First Year & Last Year & No. Years & Test Z & $p$ Value & $\begin{array}{l}\text { Sen's slope } \\
\left(m^{3} \mathrm{~s}^{-1} \mathrm{yr}^{-1}\right)\end{array}$ \\
\hline Sucío & 1976 & 2010 & 35 & 1.51 & n.s. & 0.967 \\
\hline Mulatos & 1977 & 2010 & 34 & 1.79 & $p<0.10$ & 0.044 \\
\hline Sinú & 1970 & 2010 & 41 & 1.22 & n.s. & 0.982 \\
\hline \multicolumn{7}{|l|}{ Magdalena } \\
\hline Calamar & 1941 & 2010 & 70 & 2.02 & $p<0.05$ & 17.260 \\
\hline Canal del Dique & 1979 & 2010 & 32 & 3.78 & $p<0.01$ & 7.245 \\
\hline Aracataca & 1965 & 2010 & 46 & 0.55 & n.s. & 0.025 \\
\hline Fundación & 1958 & 2010 & 53 & 2.01 & $p<0.05$ & 0.131 \\
\hline Frío & 1965 & 2010 & 45 & 1.46 & n.s. & 0.049 \\
\hline Palomino & 1973 & 2010 & 38 & 0.85 & n.s. & 0.084 \\
\hline Ranchería & 1976 & 2007 & 35 & 0.37 & n.s. & 0.039 \\
\hline
\end{tabular}

Note. n.s.: not significant; $Z_{(1-\alpha / 2)}=1.77$

All test parameter indicates not significant statistical trends in annual streamflows, except for Mulatos, Magdalena (at Calamar), Canal del Dique, and Fundacion Rivers that have increasing trends significant at 90\%, 95\%, 99\%, and 95\% confidence level, respectively (Table 3). The magnitude of discharge change per unit time period (i.e. Sens's slope) is highest in Magdalena River at Calamar and Canal del Dique. Previous studies did not report significant statistical trends in annual streamflows of rivers draining the Caribbean alluvial plain of Colombia (e.g. Mesa et al., 1997, Poveda, 2001), especially for Magdalena River (e.g. Milliman et al., 2008; Walling, 2008). These studies used different hydrological records, but none of them covered the period from 2000 to 2010. During this period, the annual streamflow of these fluvial systems rose up three fold (Figure 3). In general, the Mann-Kendall test indicates that upward trends are more pronounced after 2000 (Figure 3), even for those rivers that not show a significant statistical increase of streamflow (Figure 3a).
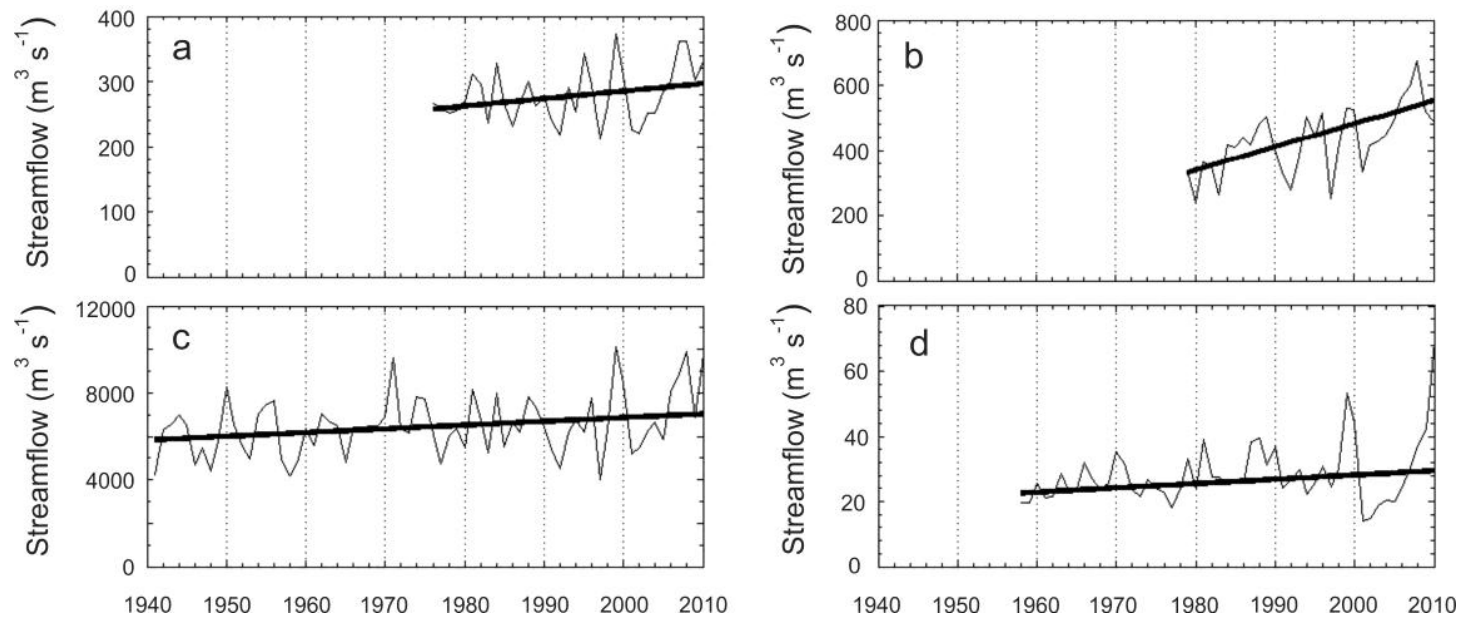

Figure 3. Mean annual streamflow (thin line) and long-term trend (Sen's slope) (bold line) for (a) Sucío, (b) Canal del Dique, (c) Magdalena (Calamar), and (d) Fundación Rivers.

\section{Annual Cycle and ENSO Effects on Freshwater Discharges}

We estimated the annual cycle of freshwater discharge using the entire hydrological record (Table 1). To explore the ENSO induced impacts on the annual cycle of freshwater discharges mean monthly streamflows are estimated during normal, El Niño (warm phase of ENSO), and La Niña (cold phase of ENSO) years (Figure 4). The months corresponding to El Niño and La Niña events were established according to NOAA (2012). In Colombia, the ENSO cold phase (La Niña) promotes a decrease in mean air temperatures, an increase in soil moisture and vegetation index, and an increase in rainfall rates. Thus, this event enhances the streamflows especially in those basins located in the Cordillera de los Andes. The opposite anomalies are common during the warm phase (El Niño) (Poveda et al., 2001).

These rivers have a strong annual cycle with maximum freshwater discharges at may-april and october-december. The dry season corresponds to february-march (Figure 4). The Sucío, Sinú, Canal del Dique, and Magdalena Rivers exhibit higher and lower streamflows through all annual cycle during 
La Nina y El Nino, respectively. These differences are noticeable at extremes of annual cycle, but significantly lower at the second quarter (Figure 4). On the contrary, the annual cycle of some rivers does not undergo significant differences during normal, El Niño and La Niña years; even, the highest streamflows of the second quarter (april-june) occur during Normal or El Nino years (Figure 4). Poveda et al. (2001) have noted previously the weak simultaneous correlation between ENSO and streamflows during april-may-june in Colombia, because ENSO is either just starting to develop or is declining at that time of the year.
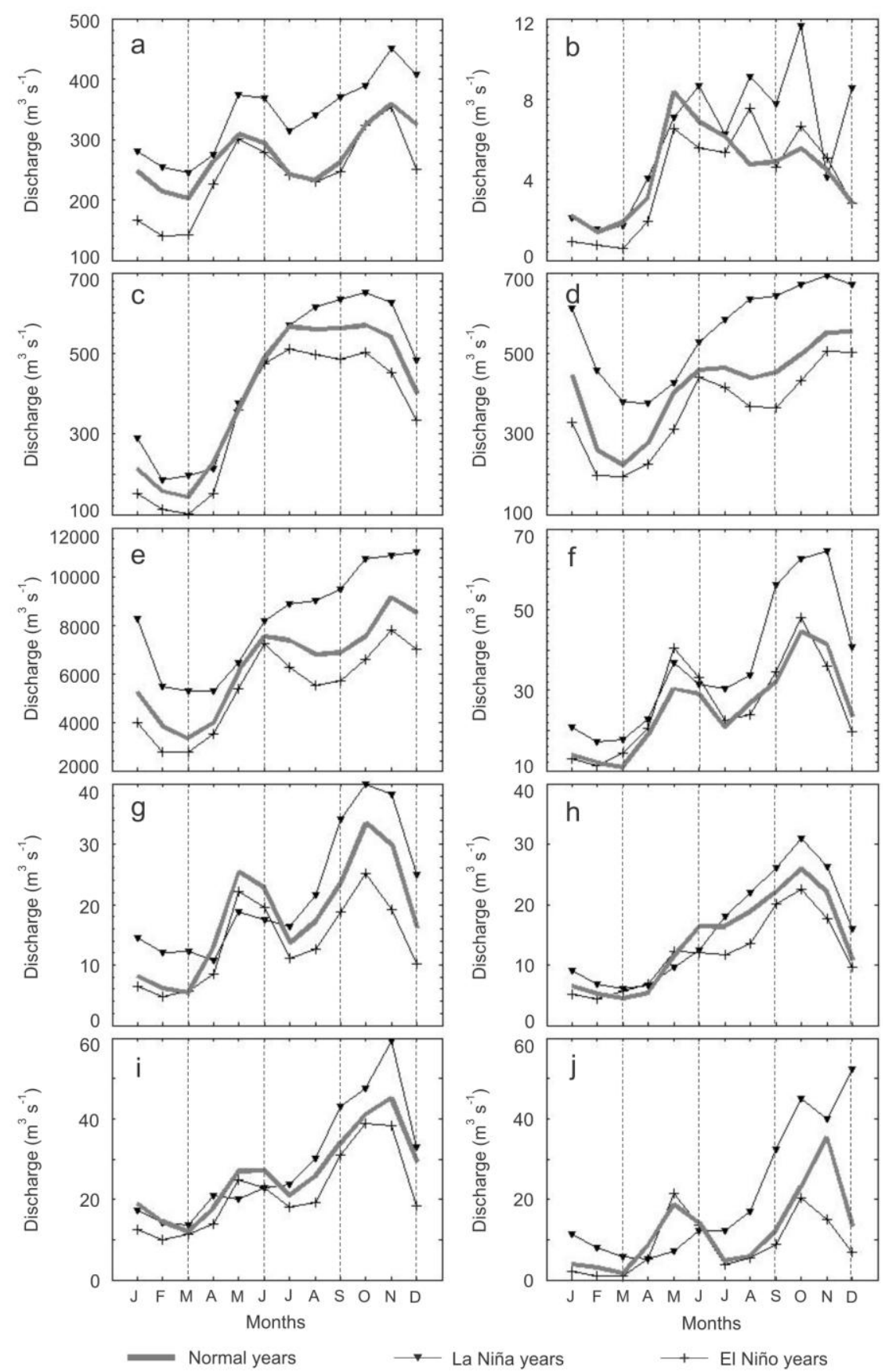

Figure 4. Seasonal freshwater discharge of (a) Sucío, (b) Mulatos, (c) Sinú, (d) Canal del Dique, (e) Magdalena (Calamar), (f) Fundación, (g) Aracataca, (h) Frío, (i) Palomino, and (j) Ranchería Rivers during normal, La Nina, and El Nino years. 
The influence of ENSO on hydrological cycle has been analyzed at interannual scales in South America (i.e. Amarasekera et al., 1997; Robertson and Mechoso, 1998; Labat el al., 2005; Pasquini and Depetris, 2007). For example, Amarasekera et al. (1997) found a weak correlation between the Pacific surface sea temperature anomalies and annual discharge of Amazon River, with ENSO explaining less than $10 \%$ of the annual streamflow variability. On the contrary, a Wavelet Spectrum analysis of annual streamflow of Amazon River indicates a 3-6 year oscillation typical of ENSO variability, and nearly permanent 2-year coherence between SOI index and Amazon discharge (Labat et al., 2005). In Parana and Patagonia basins a spectral analyses of streamflow time series pointed out that ENSO phenomenon and pressure anomalies over the South Atlantic Ocean control the shifts and oscillations of the hydrologic regimes in southeastern South America (Pasquini and Depetris, 2007). However, the effects of ENSO over interannual variability of streamflow have been evaluated in few rivers of the Caribbean alluvial plain of Colombia (e.g. Restrepo and Kjerfve, 2000; Gutierrez and Declet, 2001; Poveda et al., 2001).

Between 1950 and 2010 there were 11 and 8 moderate to strong El Niño and La Niña events, respectively (NOAA, 2012). High monthly streamflow and SOI positive anomalies are moderately to highly correlated; thus high freshwater discharges correspond to positive SOI anomalies. For example, SOI anomaly reached more than 3 in 2010 and by this time most of the rivers of the Caribbean alluvial plain underwent anomalously high streamflows (Figure 5). On the contrary, low monthly streamflows and SOI negative anomalies are moderately to poorly correlated in Andean Rivers, and poorly correlated in Sierra Nevada Rivers. The extreme negative SOI anomalies of 1982, 1987 and 2007 do not coincide with excessive low streamflows, especially in Fundación River (draining the Sierra Nevada de Santa Marta) (Figure 5). These results suggest that other climate drivers might contribute to explain the streamflow variability of rivers draining the Caribbean alluvial plain of Colombia; ENSO acts as a source of variability that enhances or diminishes the effects of other climate oscillations (e.g. Labat et al. 2005; Labat, 2008; Pasquini and Depetris, 2007).



Figure 5. Monthly standardized streamflow for Fundación and Magdalena Rivers, and SOI Index anomalies (thin line); a five-month moving average is superimposed on time series (black bold line). Dark gray and light gray boxes represent cold and warm phases of ENSO phenomenon, respectively.

\section{Periodicities: Short and Long Term Processes of Freshwater Discharges}

The Continuous Wavelet Transform was applied on monthly deseasonalized streamflows to estimate periodicities and variability patterns. This analysis makes possible to distinguish temporal 
oscillations in time series, identifying the intermittency of each time-scale processes (Figure 6). The 6month process appears highly intermittent and relatively scarce for most of the rivers. The Sucío and Magdalena streamflows 6-month component is visible around 1976-1994 and 2002-2010. The temporal dynamics of annual oscillation also varies among these rivers. The annual signal appears as stationary for the Sinú River; whereas Magdalena and Frio Rivers are characterized by a quasi non-intermittent 1year process of comparable magnitude across the hydrological record. Some streamflows highlight an intermittent annual process. For example, Sucío, Fundación and Palomino Rivers exhibit short periods of intense activity over the 1985-1990 and 2005-2010 intervals (Figure 6) that coincides with an increase in freshwater discharge during these periods.
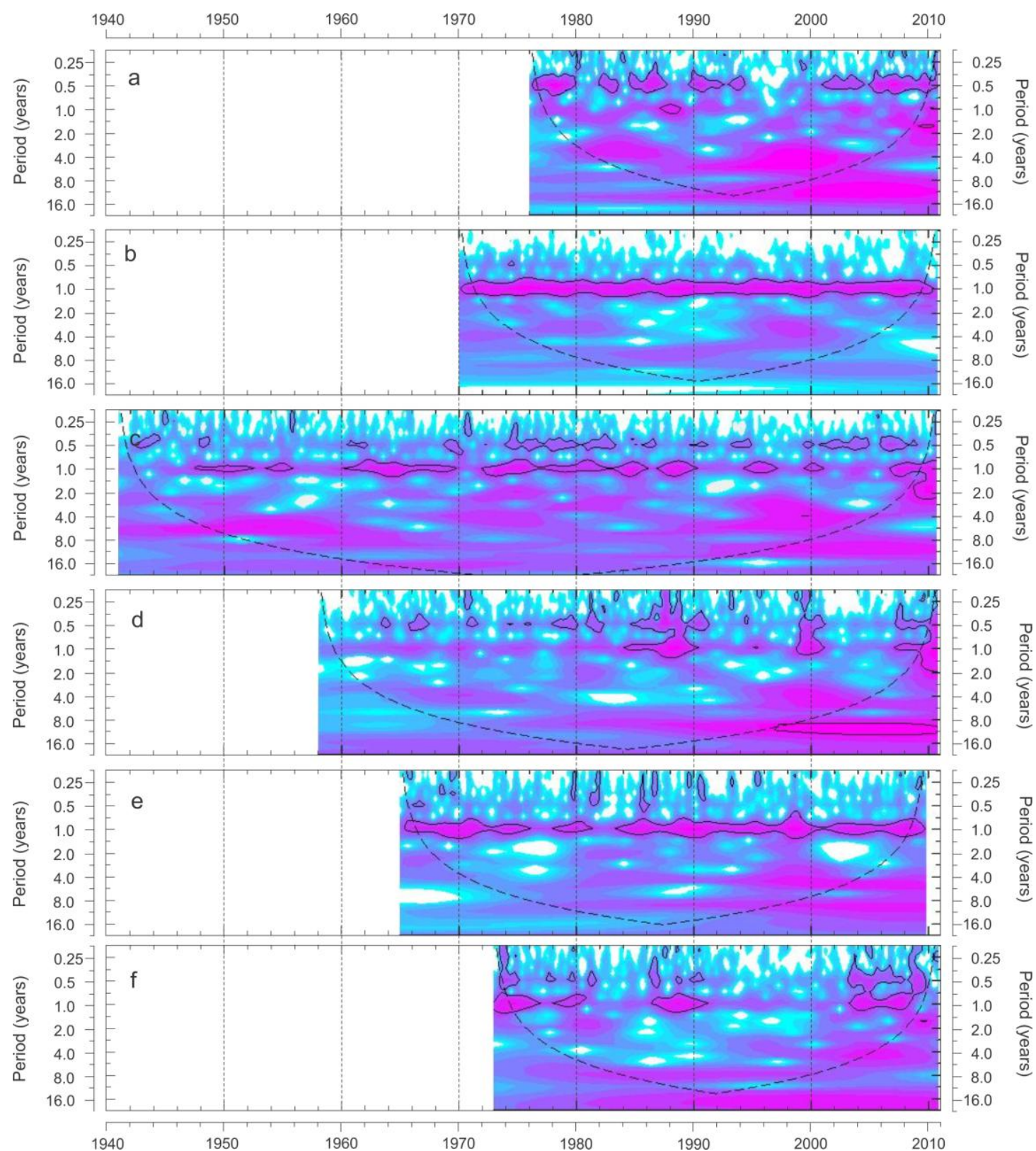

Figure 6. Continuous Wavelet transform spectrum for (a) Sucío, (b) Sinú, (c) Magdalena (Calamar), (d) Fundación, (e) Frío, (f) Palomino Rivers. Dark purple in the wavelet spectra correspond to high values of the transform coefficients (power).

The interannual streamflow fluctuations in these fluvial systems are characterized by an intermittent 3-7 year process (ENSO band variability). Sucío streamflow wavelet spectrum highlights a 3-4 year process over the 1980-1988 interval and a 4-7 year process between 1995 and 2005. The 3-7 
year process also appears in Sinú and Fundación Rivers over the 1995-2005 period; whereas it extends from 1996 to 2010 in Frío and Palomino Rivers. Magdalena freshwater discharge exhibit a 5-7 year oscillation over the 1948-1960 interval, a 3-4 year process between 1970 and 1976, and a major 3-7 year oscillation over the 1994-2004 period (Figure 6). A strong quasi-decadal oscillation (8-12 year) appears in most of the rivers around 1998 and extends to 2010. The wavelet spectrum highlights a period of intense activity around 1998-2002, where the major oscillations appear as concurrents. For example, the Fundación freshwater discharge exhibits superimposed oscillations of 0.5-1 year, 4-7 year, and 9-12 year, over the 1998-2002 interval (Figure 6d). The superposition of oscillatory signal also occurs in Palomino River between 2004 and 2010 (Figure 6f). Finally, a quasi-biennial oscillation arises in streamflow of Magdalena and Fundación Rivers around 2009 (Figure 6). This fluctuation conjugates with a 9-10 year process and coincides with a period of severe floods in the Caribbean alluvial plain.

The wavelet spectrum can be averaged in time to quantify the main scales of the underlying processes, allowing the determination of the variance signal distribution between the different scales (Torrence and Compo, 1998). Thus, this time averaging processes leads to the global wavelet spectrum (Figure 7). The 6-months and 1-year component are visible using this averaging technique. Their intensity is of the same magnitude (or lower) as that of large scale processes. Precisely, the decisive advantage of global wavelet spectrum consists of its efficient estimation of the characteristic scales of the long-term processes (Labat et al., 2005). On interannual scales, a 3-7 year oscillation is common in these fluvial systems, except in Sinú and Aracataca Rivers that exhibit a strong annual and quasidecadal oscillation, respectively (Figure 7). Most of the streamflow series show an 8-12 year fluctuation (quasi-decadal); this is the main oscillatory component in Sucío, Dique, Fundación and Aracataca Rivers. On a multidecadal scales, a 19-year oscillation is highlighted in both Palomino and Ranchería River streamflows (Figure 7).
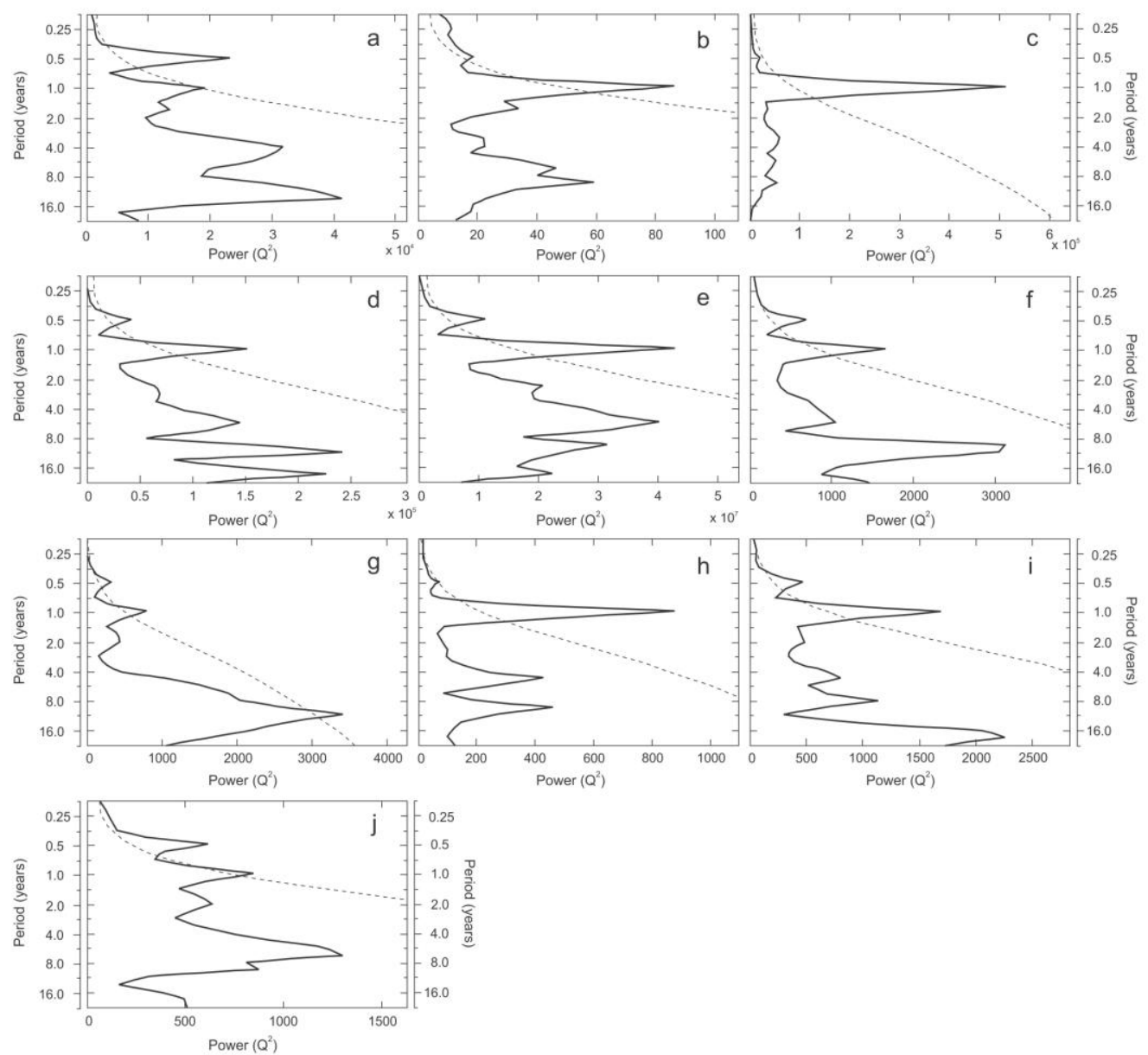

Figure 7. Global Wavelet Spectrum for (a) Sucío, (b) Mulatos, (c) Sinú, (d) Canal del Dique, (e) Magdalena, (f) Fundación, (g) Aracataca, (h) Frío, (i) Palomino, and (j) Ranchería Rivers. 


\section{CONCLUSSIONS}

The rivers of Colombia contribute with $\sim 340.9 \mathrm{~km}^{3} \mathrm{yr}^{-1}$ of freshwater into the Caribbean Sea. The Magdalena River is the largest supply of freshwater into the Caribbean Sea, with a mean discharge at Calamar of $205.5 \mathrm{~km}^{3} \mathrm{yr}^{-1}$ that represent $26 \%$ of the total fluvial discharge into this basin. The MannKendall indicated not significant statistical trends in annual streamflows, except for upward trends in Mulatos, Magdalena (at Calamar), Canal del Dique, and Fundación Rivers. However, from 2000 to 2010 the annual streamflow of the examined rivers rose up three fold.

When considering the historical discharge variability, the Wavelet analysis produced evidence of annual, interannual (3-7 year), and quasi-decadal (8-12 year) periodicities. Most of the rivers in the region exhibited moderately strong El Niño-like interannual periodicities with the exception of the Sinú River. In most of the rivers the wavelet spectrum highlighted a period of intense activity around 19982002 defined by the concurrence of the major oscillation processes and the maximum power of the 3-7 year fluctuation. Besides, the analysis highlighted a change in hydrological response of fluvial systems at the end of the hydrological record (2000-2010), characterized by a shift toward a domain of quasidecadal processes. Precisely, this signal is the major oscillatory component in some rivers.

The Intertropical Convergence Zone (ITCZ) migration (0.5-1 yr process) and ENSO phenomenon (2-6 yr process) are the main climatic factors controlling fluvial discharges variability of rivers draining the Caribbean alluvial plain. However, in the last 20 years a signal that could be associated to quasidecadal climate processes (e.g. sea surface temperatures anomalies over Tropical North Atlantic TNA; Pacific Decadal Oscillation - PDO) contributed to enhance the interannual signal that reached its maximum power around 1998 and 2010.

\section{ACKNOWLEDGMENTS}

We wish to acknowledge to Universidad Pontificia Bolivariana (CIDI) in Monteria (Colombia) and The Research Office (Dirección de Investigación Desarrollo e Innovación - DIDI) of Universidad del Norte (Colombia) for funding this research, and the Center of Excellence for Development of Marine Sciences of Colombia CEMarin - DAAD of Germany.

\section{REFERENCES}

Amarasekera, K., R. Lee, E. Williams, and E. Elthair, 1997. ENSO and the natural variability in the flow of tropical rivers. Journal of Hydrology, 200, 24-39.

Garcia N., and C. Mechoso. 2005. Variability in the discharge of South American rivers and in climate. Journal of Hydrological Sciences, 50(3), 459-478.

GRDC (Global Runoff Data Centre), 2009. Surface freshwater fluxes into the world oceans from land areas associated with GIWA regions between $170 \mathrm{E}$ and 10E. Online Reports. (http://www.bafg.de/cln_031/nn_294146/GRDC/EN/01_GRDC/grdc_node.html? nnn=true) (January 2012).

Gutierrez, F., and J. Dracup. 2001. An analysis of the feasibility of long-range streamflow forecasting for Colombia using El Nino - Southern Oscillation indicators. Journal of Hydrology, 246, 181196.

Hungtinton T. 2006. Evidence for intensification of the global water cycle: review and synthesis. Journal of Hydrology, 319, 83-95.

Labat, D. 2005. Recent advances in wavelet analyses: Part 1 - A review of concepts. Journal of Hydrology, 314, 275-288.

Labat, D. 2008. Wavelet analysis of the annual discharge records of the world's largest rivers. Advances in Water Resources, 31, 109-117.

Labat, D. 2010. Cross wavelet analyses of annual continental freshwater discharge and selected climate indices. Journal of Hydrology, 385, 269-278.

Labat, D., J. Ronchail, and J.L. Guyot. 2005. Recent advances in wavelet analyses: Part 2 - Amazon, Parana, Orinoco and Congo discharges time scale variability. Journal of Hydrology, 314, 289-311.

Labat, D., J. Ronchail, J. Callede, J.L. Guyot, E. de Oliveira, and W. Guimares. 2004. Wavelet analysis of Amazon hydrological regime variability. Geophysical Research Letter, 31, L02501.

Mesa O., G.. Poveda, and L. Carvajal. 1997. Introducción al clima de Colombia, Universidad Nacional de Colombia, Bogotá, Colombia, 390 pp. 
Milliman, J.D., K. Farnsworth, P. Jones, K. Xu, and L.C. Smith. 2008. Climatic and anthropogenic factors affecting river discharge to the global ocean, 1951-2000. Global and Planetary Change, $62,187-194$.

NOAA (National Oceanic and Atmospheric Administration), 2012. National Weather Service - Climate Prediction Center. United States. Base de datos en línea (http://www.cpc.ncep.noaa.gov/products/analysis_monitoring/ensostuff/ensoyears.shtml) (April 2012).

Pasquini, A., and P. Depetris. 2007. Discharge trends and flow dynamics of South American rivers draining the southern Atlantic seaboard: An overview. Journal of Hydrology, 333, 385-399.

Pekarova, P., P. Miklanek, and J. Pekar. 2003. Spatial and temporal runoff oscillation analysis of the main rivers of the world during the 19th-20th centuries. Journal of Hydrology, 274. 62-79.

Poveda G. 2004. La hidroclimatología de Colombia: una síntesis desde la escala inter-decadal hasta la escala diurna. Revista de la Academia Colombiana de Ciencias Exactas, Físicas y Naturales, 28(107), 201-222.

Poveda G., A. Jaramillo, M. Gil, N. Quiceno, and R. Mantilla. 2001. Seasonality in ENSO-related precipitation, river discharges, soil moisture, and vegetation index in Colombia. Water Resources Research, 37(8), 2169-2178.

Probst, J.L., and Y., Tardy. 1987. Long range streamflow and world continental runoff fluctuations since the beginning of this century. Journal of Hydrology, 94, 289-311.

Restrepo J.C., and J.D. Restrepo. 2005. Efectos Naturales y Antrópicos en la Producción de Sedimentos de la Cuenca del Río Magdalena. Revista de la Academia Colombiana de Ciencias Exactas, Físicas y Naturales, 29 (111), 239-254.

Restrepo J.D., and B. Kjerfve. 2000. Magdalena river: interannual variability (1975-1995) and revised water discharge and sediment load estimates. Journal of Hydrology, 235, 137-149.

Restrepo J.D., and B. Kjerfve. 2004. The Pacific and Caribbean Rivers of Colombia: Water Discharge, Sediment Transport and Dissolved Loads. pp 169-187. En: Lacerda L., Santelli R., Duursma, E., Abrao, J. 2004. Environmental Geochemistry in Tropical and Subtropical Environments. Springer Verlag, Berlín, Germany. 455 p.

Rossi A., B. Massei, D. Laignel, D. Sebag, and Y. Copard. 2009. The response of the Mississippi River to climate fluctuations and reservoir construction as indicated by wavelet analysis of streamflow and suspended sediment load. Journal of Hydrology, 377, 237-244.

Serrano, B. 2004. The Sinú river delta on the northwestern Caribbean coast of Colombia: bay infilling associated with delta development. Journal of South American Earth Sciences, 16, 639-647.

Shumway R., and D. Stoffer. 2004. Time Series Analysis and Its Applications, Springer-Verlag, Amsterdam, The Netherlands, 543 pp.

Torrence C., and G. Compo. 1998. A Practical Guide to Wavelet Analysis. Bulletin of the American Meteorological Society, 79(1), 61-78.

Walling D., and Fang. 2003. Recent trends in the suspended sediment loads of the world's rivers. Global and Planetary Change, 39, 111-126.

Zhang S., X. Lu, D. Higgit, A. Chen, J. Han, and H. Sun. 2008. Recent changes of water discharge and sediment load in the Zhujiang (Pearl River) Basin, China. Global and Planetary Change, 60, 365380 .

Yue S., P. Pilon, and G. Cavadias. 2002. Power of the Mann-Kendall and Spearman's rho test to detecting monotonic trends in hydrological series. Journal of Hydrology, 259, 254-271. 